\title{
Legionella waltersii sp. nov. and an Unnamed Legionella Genomospecies Isolated from Water in Australia
}

\author{
ROBERT F. BENSON, ${ }^{1 *}$ W. LANIER THACKER, ${ }^{1}$ MARYAM I. DANESHVAR, ${ }^{2}$ AND DON J. BRENNER ${ }^{2}$ \\ Childhood and Respiratory Diseases Branch ${ }^{1}$ and Emerging and Mycotic Diseases Branch, ${ }^{2}$ Division of Bacterial and \\ Mycotic Diseases, National Center for Infectious Diseases, Centers for Disease Control and Prevention, \\ Public Health Service, U.S. Department of Health and Human Services, Atlanta, Georgia 30333
}

\begin{abstract}
Two Legionella-like organisms were isolated from water samples obtained in Adelaide, Australia. One organism was isolated from a drinking water distribution system, and the other was isolated from a cooling tower at a sewage treatment plant. Both strains required $L$-cysteine for growth and contained cellular branched-chain fatty acids and ubiquinones typical of the genus Legionella. These strains were serologically distinct from each other as determined by a slide agglutination test. Strain $2074-A U S-E^{T}(T=$ type strain) was serologically distinct from all previously described Legionella species and serotypes. Strain 2055-AUS-E could not be differentiated biochemically or serologically from Legionella quinlivanii. Both strains were shown by DNA hybridization studies (hydroxyapatite method) to be members of new Legionella species. Legionella waltersii $\mathrm{sp}$. nov. is the name proposed for strain 2074-AUS-E ${ }^{\mathrm{T}}$ (= ATCC 51914 ${ }^{\mathrm{T}}$ ). L. waltersii was less than $10 \%$ related to other Legionella species. Strain 2055-AUS-E (= ATCC 51913) was informally named Legionella genomospecies 1 , since it could not be phenotypically distinguished from $L$. quinlivanii. Legionella genomospecies 1 was closely related to $L$. quinlivanii strains $\left(53\right.$ to $69 \%$ related with 4.5 to $6.5 \%$ divergence at $60^{\circ} \mathrm{C}$ and 31 to $52 \%$ related at $7^{\circ} \mathbf{C}$ ).
\end{abstract}

Of the 39 previously described Legionella species $(8,17,19)$, 3 were isolated from water in Australia. These three species are Legionella adelaidensis (2), Legionella quinlivanii (3), and Legionella fairfieldensis (16). Between March 1987 and April 1988, 35 additional Legionella-like organisms were isolated from cooling tower water samples and from a drinking water supply distribution system in Adelaide, South Australia, Australia. A total of 33 of these organisms were identified as members of previously described Legionella species and serogroups by a slide agglutination test (18). In this paper we describe the growth, physiological characteristics, cellular fatty acid compositions, isoprenoid quinone contents, serological characteristics, and levels of DNA relatedness of the other two isolates, which represent two new Legionella species; these species are Legionella waltersii sp. nov. and unnamed Legionella genomospecies 1 .

\section{MATERIALS AND METHODS}

Strains. Type and reference strains representing 39 species and 59 serogroups of the genus Legionella were obtained from the culture collection of the Centers for Disease Control and Prevention, Atlanta, Ga., or from the National Collection of Type Cultures. These organisms were representative of Legionella pneumophila serogroups 1 through 15, Legionella bozemanii serogroups 1 and 2 , Legionella dumoffi, Legionella gormanii, Legionella micdadei, Legionella longbeachae serogroups 1 and 2, Legionella jordanis, Legionella oakridgensis, Legionella wadsworthii, Legionella feeleii serogroups 1 and 2, Legionella sainthelensi serogroups 1 and 2, Legionella anisa, Legionella santicrucis, Legionella steigerwaltii, Legionella parisiensis, Legionella spiritensis, Legionella hackeliae serogroups 1 and 2, Legionella maceachernii, Legionella jamestowniensis, Legionella cherrii, Legionella rubrilucens, Legionella erythra, Legionella israelensis, Legionella birminghamensis, Legionella cincinnatiensis, Legionella quinlivanii serogroups 1 and 2, Legionella moravica, Legionella brunensis, Legionella tucsonensis, Legionella gratiana, Legionella fairfieldensis, Legionella adelaidensis, Legionella shakespearei, Legionella lansingensis, Legionella quateirensis, Legionella worsleiensis, Legionella geestiana, Legionella nautarum, and Legionella londiniensis.

Isolation procedure. Bacteria from samples of cooling tower water and a drinking water distribution system were processed by protocols developed at the

* Corresponding author. Mailing address: Centers for Disease Control and Prevention, Bldg. 5, Room 136, Mail stop CO2, Atlanta, GA 30333. Phone: (404) 639-3563.
Centers for Disease Control and Prevention (9), with slight modifications. Bacteria from each 400-ml sample were concentrated on membrane filters (pore size, $0.2 \mu \mathrm{m}$; Sartorius, Westbury, N.Y.). The filters were placed in $20 \mathrm{ml}$ of sterile tap water, and the bacteria were resuspended by sonicating the preparation for 15 min. A $1-\mathrm{ml}$ portion of the concentrated suspension was acidified, allowed to stand for $15 \mathrm{~min}$, and then neutralized; then $0.1-\mathrm{ml}$ portions of the original and acid-treated suspensions were inoculated onto buffered charcoal-yeast extract (BCYE) agar plates and antimicrobial agent-supplemented (Oxoid MWY supplement) BCYE agar plates containing (per $100 \mathrm{ml}$ ) $0.3 \mathrm{~g}$ of glycine, 5,000 IU of polymyxin $\mathrm{B}, 8 \mathrm{mg}$ of anisomycin, $100 \mu \mathrm{g}$ of vancomycin, $1 \mathrm{mg}$ of bromothymol blue, and $1 \mathrm{mg}$ of bromocresol purple. All plates were incubated at $37^{\circ} \mathrm{C}$ in the presence of $3 \% \mathrm{CO}_{2}$. Colonies that resembled colonies of previously described Legionella species were subcultured on plates containing BCYE agar, BCYE agar without L-cysteine, and blood agar. Isolates that grew on BCYE agar but not on BCYE agar without L-cysteine or on blood agar after 3 days of incubation were presumptively identified as Legionella strains and were sent to the Centers for Disease Control and Prevention for further study.

Growth and biochemical tests. Organisms from single colonies of strains 2055-AUS-E and 2074-AUS- $E^{\mathrm{T}}$ ( $\mathrm{T}$ = type strain) were grown on BCYE agar for all tests, except that the buffer was omitted for determinations of autofluorescence and cysteine was omitted for determinations of a cysteine requirement (21). Physiological tests for catalase, gelatinase, oxidase, urease, and $\beta$-lactamase activities, hippurate hydrolysis, nitrate reduction, glucose fermentation, flagellation, autofluorescence, and browning of tyrosine-supplemented agar and the initial analysis to determine whole-cell fatty acid contents were performed as described previously $(7,11)$.

Cellular fatty acids and isoprenoid quinones. The cells used for fatty acid and isoprenoid quinone analyses were grown for 48 to $96 \mathrm{~h}$ at $35^{\circ} \mathrm{C}$ on BCYE agar plates. Cellular fatty acids were saponified, processed, and analyzed as methyl esters by capillary gas-liquid chromatography as described previously $(11,12,14)$. Isoprenoid quinones were extracted from 100 to $200 \mathrm{mg}$ of lyophilized cells and analyzed by reverse-phase high-performance liquid chromatography (13). The identities of individual fatty acids and quinones were confirmed by mass spectrometry $(10,11)$.

Slide agglutination test. Strains 2055-AUS-E and 2074-AUS- $E^{\mathrm{T}}$ were tested with antisera to 39 previously characterized Legionella species and 59 serogroups $(4,5,8,17,19)$. Antisera to strains 2055 -AUS-E and 2074-AUS-E ${ }^{\mathrm{T}}$ were prepared, tested, and absorbed as described previously (18). Antigens and antisera for L. erythra serogroup 2 (15) were not available for testing.

DNA methods. The methods used to isolate and purify DNA have been described previously (6). DNAs from strains 2055-AUS-E and 2074-AUS-E ${ }^{\mathrm{T}}$ and L. quinlivanii $1442-$ AUS-E $^{\mathrm{T}}\left(=\right.$ ATCC $43830^{\mathrm{T}}$ ) were labeled enzymatically in vitro as described previously (7). Levels of DNA relatedness were determined by using the free-solution hydroxyapatite method performed at 60 and $75^{\circ} \mathrm{C}(7)$. We tested the type strains of all previously described Legionella species except $L$. anisa, L. rubrilucens, L. cherrii, L. steigerwaltii, and L. santicrucis (7). Each of these five species is at least $50 \%$ related to a species that was tested and that 
TABLE 1. Cellular fatty acid compositions of strains 2055-AUS-E and 2074-AUS-E ${ }^{\mathrm{T}}$

\begin{tabular}{lcc}
\hline & \multicolumn{2}{c}{$\%$ of total fatty acids $^{b}$} \\
\cline { 2 - 3 } Fatty acid & \\
\cline { 2 - 3 } & Strain & Strain \\
2055-AUS-E & 2074-AUS-E \\
\hline $\mathrm{i}-14: 0$ & 2 & 13 \\
$\mathrm{n}-14: 0$ & $\mathrm{Tr}$ & 2 \\
$\mathrm{i}-15: 0$ & 1 & $\mathrm{Tr}$ \\
$\mathrm{a}-15: 0$ & 23 & 9 \\
$\mathrm{n}-15: 1$ W6C & 4 & 6 \\
$\mathrm{n}-15: 0$ & 3 & 6 \\
$\mathrm{i}-16: 0$ & 21 & 17 \\
$\mathrm{n}-16: 1$ W7C & 18 & 19 \\
$\mathrm{n}-16: 0$ & 10 & 16 \\
$\mathrm{i}-17: 0$ & 1 & $\mathrm{ND}$ \\
$\mathrm{a}-17: 0$ & 12 & 2 \\
$\mathrm{n}-17: 0$ & 2 & 2 \\
$\mathrm{n}-18: 0$ & $\mathrm{Tr}$ & 2 \\
$\mathrm{n}-19: 0$ & $\mathrm{Tr}$ & 1 \\
$\mathrm{n}-20: 0$ & 1 & 3 \\
\hline
\end{tabular}

${ }^{a}$ The number before the colon is the number of carbon atoms, and the number after the colon is the number of double bonds; $n$ is a normal unbranched fatty acid; $\mathrm{i}$ indicates that there is a methyl branch at the iso carbon atom; $\mathrm{a}$ indicates that the methyl branch is at the anteiso carbon atom; $\mathrm{W}$ is the double bond position from the hydrocarbon end of the chain; and $\mathrm{c}$ is the cis isomer.

${ }^{b}$ The values are arithmetic means determined from an analysis of three or more separate cultures of each strain. Tr, trace (less than $0.8 \%$ ); ND, not detected.

exhibited less than $10 \%$ relatedness to strains $2055-$ AUS-E and 2074-AUS-E ${ }^{\mathrm{T}}$. Therefore, it was not necessary to test them directly.

\section{RESULTS}

Growth characteristics and biochemical tests. The two Legionella-like isolates were gram-negative rods with single polar flagella. They were typical of Legionella species in that they required L-cysteine for growth. No autofluorescence was observed when the isolates were exposed to long-wavelength (365-nm) UV light. Both strains gave negative results in physiological tests for reduction of nitrate to nitrite, urease activity, and acid production from D-glucose. They were both positive in catalase and gelatinase reactions. Strain 2055-AUS-E was positive for browning of tyrosine-supplemented agar and was negative for oxidase and $\beta$-lactamase activities and hippurate hydrolysis. Strain $2074-A U S-E^{\mathbf{T}}$ was positive for hippurate hydrolysis and oxidase and $\beta$-lactamase activities and negative for browning of tyrosine-supplemented agar.

Cellular fatty acid and isoprenoid quinones. The cellular fatty acid compositions of strains 2055-AUS-E and 2074-AUS$E^{\mathrm{T}}$ are shown in Table 1. Strain 2055-AUS-E contained about equal amounts of a-15:0 and i-16:0 (23 and $21 \%$, respectively), which were the two major components, followed by $16: 1$ W7C $(18 \%)$, a-17:0 (12\%), and 16:0 (10\%). No hydroxy acids were detected in saponified cells, and the hydroxy acid fraction from acid-hydrolyzed cells was less than $2 \%$ of the total fatty acids. Strain 2074-AUS-E ${ }^{\mathrm{T}}$ had a unique cellular fatty acid profile, which was characterized by the presence of nearly equal amounts of 16:1 W7C, i-16:0, 16:0, and i-14:0. Strain 2055AUS-E contained ubiquinones with 11, 12, and 13 isoprene units in the polyprenoid side chain (ubiquinones 11, 12, and 13, respectively). Ubiquinone 13 was the major ubiquinone in 2055-AUS-E and was present at a concentration that was about two times the concentration of ubiquinone 12 and three times the concentration of ubiquinone 11. Strain 2074-AUS-E ${ }^{\mathrm{T}}$ contained ubiquinones $10,11,12$, and 13. In strain 2074-AUS-
$\mathrm{E}^{\mathrm{T}}$ ubiquinone 12 was the major quinone, and about equal amounts of ubiquinones 10,11 , and 13 were present at concentrations that were approximately $50 \%$ of the concentration of ubiquinone 12 .

Slide agglutination test. Strain 2074-AUS-E ${ }^{\mathrm{T}}$ reacted weekly $(1+)$ with unabsorbed antisera to $L$. worsleiensis and $L$. fairfieldensis and did not agglutinate with antisera to any of the other previously described Legionella species or serogroups tested. Antiserum to 2074-AUS- $E^{\mathrm{T}}$ agglutinated only the 2074AUS- $E^{\mathbf{T}}$ antigen at a working dilution of 1:8. Strain 2055AUS-E reacted $1+$ with unabsorbed antiserum to $L$. quinlivanii serogroup 2 strain LC 870 (= NCTC 12434) and was negative with all other Legionella species and serogroups tested. Antiserum to strain 2055-AUS-E agglutinated the 2055AUS-E antigen $4+$ at a dilution of 1:16 and cross-reacted $4+$ with $L$. quinlivanii serogroup 2 . It did not agglutinate with any other Legionella species or serogroup antigens or the 2074AUS- $E^{\mathrm{T}}$ antigen. Absorption of the antiserum to strain 2055AUS-E with $L$. quinlivanii serogroup 2 cells removed all homologous and heterologous activities.

DNA relatedness studies. In optimal $60^{\circ} \mathrm{C}$ reactions, labeled DNA from strain 2074-AUS-E ${ }^{\mathrm{T}}$ was 0 to $9 \%$ related to DNAs from all of the other legionellae tested (data not shown). The levels of relatedness of strain 2055-AUS-E DNA are shown in Table 2. Strain 2055-AUS-E was $68 \%$ related to the type strain of $L$. quinlivanii in reactions performed at $60^{\circ} \mathrm{C}$. The level of divergence for the related sequences was $5 \%$, and the level of relatedness in $75^{\circ} \mathrm{C}$ reactions was $51 \%$. The levels of relatedness of strain 2055-AUS-E to five $L$. quinlivanii serogroup 1 strains were similar $\left(60\right.$ to $69 \%$ at $60^{\circ} \mathrm{C}$ with 5.0 to $6.5 \%$ divergence and 31 to $52 \%$ at $75^{\circ} \mathrm{C}$ ). The levels of relatedness to L. quinlivanii serogroup 2 strain NCTC 12434 were $53 \%$ with $4.5 \%$ divergence at $60^{\circ} \mathrm{C}$ and $36 \%$ at $75^{\circ} \mathrm{C}$. In reciprocal reactions in which we used labeled DNA from L. quinlivanii serogroup 1 strain ATCC $43830^{\mathrm{T}}$, the levels of relatedness to other L. quinlivanii serogroup 1 strains were 91 to $99 \%$ with 0.5 to $3.0 \%$ divergence at $60^{\circ} \mathrm{C}$ and 89 to $100 \%$ at $75^{\circ} \mathrm{C}$. L. quinlivanii serogroup 1 was $79 \%$ related to $L$. quinlivanii serogroup 2 strain NCTC 12434 at $60^{\circ} \mathrm{C}$ with $0 \%$ divergence and $85 \%$ related at $75^{\circ} \mathrm{C}$. The levels of relatedness of ATCC $43830^{\mathrm{T}}$ to strain 2055 -AUS-E were $58 \%$ with $6.5 \%$ divergence at $60^{\circ} \mathrm{C}$ and $41 \%$ at $75^{\circ} \mathrm{C}$. L. birminghamensis was approximately $20 \%$ related to 2055-AUS-E and to $L$. quinlivanii. All of the other species tested exhibited less than $10 \%$ relatedness.

\section{DISCUSSION}

Strains 2055-AUS-E and 2074-AUS-E ${ }^{\mathrm{T}}$ were presumptively identified as members of the genus Legionella on the basis of their cultural and biochemical characteristics. The cellular fatty acid compositions and isoprenoid quinone contents of strains 2055-AUS-E and 2074-AUS-E ${ }^{\mathrm{T}}$ were consistent with the characteristics of all other Legionella species by virtue of their relatively high branched-chain acid contents, with only trace or minor amounts of hydroxy acids, and their isoprenoid quinones with 10 or more isoprene units in the side chains $(10$, 11).

Strain 2074-AUS-E ${ }^{\mathrm{T}}$ could be distinguished from other members of the genus Legionella by its cellular fatty acid composition. The presence of $\mathrm{i}-14: 0$ as a major acid $(13 \%)$ is useful for differentiating this organism, since all other Legionella species (except $L$. gratiana and $L$. shakespearei) contain less than $10 \%$ i-14:0. Strain 2074-AUS-E ${ }^{T}$ can be easily distinguished from $L$. gratiana by the absence of $17: 0$ cyc and by its smaller amount of i-16:0 (17 versus $31 \%$ ) and from $L$. shakespearei by its smaller amount of $\mathrm{i}-16: 0$ (17 versus $31 \%)$ and by its larger 
TABLE 2. Levels of DNA relatedness of Legionella-like strain 2055-AUS-E and L. quinlivanii ATCC $43830^{\mathrm{T}}$

\begin{tabular}{|c|c|c|c|c|c|c|}
\hline \multirow[b]{4}{*}{ Source(s) of unlabeled DNA } & \multicolumn{6}{|c|}{ Source of labeled DNA ${ }^{a}$} \\
\hline & \multicolumn{3}{|c|}{ Strain 2055-AUS-E } & \multicolumn{3}{|c|}{ L. quinlivanii ATCC $43830^{\mathrm{T}}$} \\
\hline & \multicolumn{2}{|c|}{$60^{\circ} \mathrm{C}$} & \multirow[b]{2}{*}{ 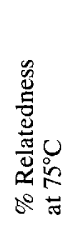 } & \multicolumn{2}{|c|}{$60^{\circ} \mathrm{C}$} & \multirow[b]{2}{*}{ 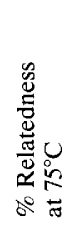 } \\
\hline & 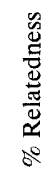 & 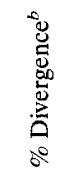 & & 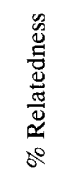 & 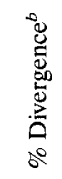 & \\
\hline Legionella-like strain 2055-AUS-E & 100 & 0.0 & 100 & 58 & 6.5 & 41 \\
\hline L. quinlivanii ATCC $43830^{\mathrm{T}}$ & 68 & 5.0 & 51 & 100 & 0.0 & 100 \\
\hline L. quinlivanii serogroup 1 strain D-1448 & 64 & 5.5 & 49 & 97 & 1.5 & 95 \\
\hline L. quinlivanii serogroup 1 strain D-1449 & 60 & 6.5 & 32 & 91 & 2.5 & 89 \\
\hline L. quinlivanii serogroup 1 strain D-1450 & 60 & 6.5 & 31 & 91 & 3.0 & 90 \\
\hline L. quinlivanii serogroup 1 strain D-1451 & 69 & 5.0 & 46 & 99 & 0.5 & 100 \\
\hline L. quinlivanii serogroup 1 strain D-1452 & 67 & 5.5 & 52 & 99 & 1.0 & 100 \\
\hline L. quinlivanii serogroup 2 strain NCTC 12434 & 53 & 4.5 & 36 & 79 & 0.0 & 85 \\
\hline L. birminghamensis ATCC $43702^{\mathrm{T}}$ & 19 & $\mathrm{ND}^{c}$ & ND & $23^{d}$ & ND & ND \\
\hline 43 other Legionella type and reference strains & $1-8$ & ND & ND & $1-5^{d}$ & ND & ND \\
\hline
\end{tabular}

a All experiments were performed at least twice.

${ }^{b}$ Levels of divergence were calculated to the nearest $0.5 \%$.

${ }^{c} \mathrm{ND}$, not done.

${ }^{d}$ Data from reference 3 .

amount of 16:0 (16 versus $8 \%$ ) (17). The quinone profile of strain 2074-AUS-E ${ }^{\mathrm{T}}$ is similar to the quinone profiles of $L$. pneumophila, L. erythra, and L. rubrilucens (11). The overall nonhydroxy acid profile of strain 2055-AUS-E is quite similar to the profiles of $L$. quinlivanii and $L$. birminghamensis $(3,22)$. The quinone profile of this organism is similar to the profiles of several other Legionella species that contain large amounts of ubiquinone 13 and were placed in ubiquinone group $\mathrm{D}$ by Lambert and Moss (11). The quinone profiles of both organisms are useful for identification at, but not below, the genus level.

The slide agglutination test results showed that strains 2055AUS-E and 2074-AUS-E ${ }^{\mathrm{T}}$ were representatives of either new Legionella species or new serogroups of previously described Legionella species. The occurrence of a cross-reaction between antiserum to 2055-AUS-E and L. quinlivanii serogroup 2 which could not be removed by absorption has been observed previously with other Legionella species $(1,18)$. DNA relatedness studies established that strain 2074-AUS- $E^{\mathrm{T}}$, which was less than $10 \%$ related to all previously described Legionella species, was a member of a new species. Strain 2055-AUS-E was closely related to both serogroups of $L$. quinlivanii. The levels of relatedness between 2055-AUS-E and $L$. quinlivanii in reciprocal reactions were 53 to $69 \%$ with 4.5 to $6.5 \%$ divergence at $60^{\circ} \mathrm{C}$, the optimal temperature for DNA reassociation, and 31 to $51 \%$ at $75^{\circ} \mathrm{C}$, a stringent temperature. The levels of relatedness between $L$. quinlivanii strains were 79 to $99 \%$ with 0.5 to $3.0 \%$ divergence at $60^{\circ} \mathrm{C}$ and 85 to $100 \%$ at $75^{\circ} \mathrm{C}$. The recommended genetic definition of a species is a group of strains that are $70 \%$ or more related with less than $5 \%$ divergence under optimal conditions for DNA reassociation $\left(60^{\circ} \mathrm{C}\right.$ reactions in this study) (20). In our laboratory, we have extended this definition to include relatedness under stringent conditions for DNA reassociation $\left(75^{\circ} \mathrm{C}\right.$ reactions in this study). Experience tells us that strains of the same species exhibit a minimal decrease in level of relatedness at the stringent incubation temperature, with the level of relatedness remaining more than $60 \%$.

Strain 2055-AUS-E was designated a genomospecies rather than given a formal name because it could not be differentiated biochemically or serologically from $L$. quinlivanii serogroup 2 . It should be noted that Birtles et al. (4) reported that $L$. quinlivanii serogroup 2 is negative for gelatin liquefaction; in our laboratory, strain LC $870(=$ NCTC 12434) was positive for gelatin liquefaction. The reason for this difference is not known. The biochemical test results for $L$. quinlivanii serogroups 1 and 2 and strain 2055-AUS-E were identical (positive for catalase activity, gelatin liquefaction, and browning of tyrosine-supplemented media and negative for $\beta$-lactamase activity, hippurate hydrolysis, and oxidase activity). Descriptions of the new Legionella species and genomospecies 1 are given below.

Description of Legionella waltersii sp. nov. Legionella waltersii (wal'ters.i.i. L. gen. n. waltersii, of Walters, to honor Reginald P. Walters, who isolated the organism, L. quinlivanii [3], and the unnamed Legionella genomospecies described below). Gram-negative rods single polar flagella. Grows on BCYE agar but not on media lacking L-cysteine. Positive for catalase activity, gelatinase activity, hydrolysis of hippurate, oxidase activity, and $\beta$-lactamase activity. Negative for reduction of nitrate to nitrite, urease activity, production of acid from D-glucose, and browning of tyrosine-supplemented agar. The cellular fatty acids are predominantly branched-chain fatty acids, and trace or minor amounts of hydroxy acids are present. The major isoprenoid quinone is ubiquinone 12 . Serologically distinct from previously described legionellae and can be identified by the slide agglutination test. The type strain of $L$. waltersii is strain 2074-AUS-E (= ATCC 51914), which was isolated from a drinking water distribution system in South Australia, Australia.

Description of Legionella genomospecies 1. Legionella genomospecies 1 is a gram-negative, rod-shaped organism with single polar flagella and grows on BCYE agar but not on media lacking L-cysteine. Positive for catalase activity, gelatinase activity, and browning of tyrosine-supplemented agar. Negative for reduction of nitrate to nitrite, urease activity, production of acid from D-glucose, $\beta$-lactamase activity, oxidase activity, and hydrolysis of hippurate. The cellular fatty acids are predomi- 
nantly branched-chain fatty acids, and trace or minor amounts of hydroxy acids are present; the major isoprenoid quinone is ubiquinone 13 . In the slide agglutination test, an antigen suspension prepared from 2055-AUS-E reacts $1+$ with $L$. quinlivanii serogroup 2. Antiserum against 2055-AUS-E reacts 4+ with $L$. quinlivanii serogroup 2 antigen at the optimal working dilution. Absorption with $L$. quinlivanii serogroup 2 cells removes all homologous and heterologous agglutinating activity. The type strain of Legionella genomospecies 1 is strain 2055AUS-E (= ATCC 51913), which was isolated from cooling tower water in South Australia, Australia.

\section{ACKNOWLEDGMENTS}

We thank C. Wayne Moss, Centers for Disease Control and Prevention, for carrying out the cellular fatty acid and quinone studies; Arnold G. Steigerwalt, Centers for Disease Control and Prevention, for assistance with the DNA relatedness studies; and Peter Quinlivan, Australian Water Quality Centre, Adelaide, South Australia, Australia, for technical assistance.

\section{REFERENCES}

1. Benson, R. F., W. L. Thacker, F. C. Fang, B. Kanter, W. R. Mayberry, and D. J. Brenner. 1990. Legionella sainthelensi serogroup 2 isolated from patients with pneumonia. Res. Microbiol. 141:453-463.

2. Benson, R. F., W. L. Thacker, J. A. Lanser, N. Sangster, W. R. Mayberry, and D. J. Brenner. 1991. Legionella adelaidensis, a new species isolated from cooling tower water. J. Clin. Microbiol. 29:1004-1006.

3. Benson, R. F., W. L. Thacker, R. P. Walters, P. A. Quinlivan, W. R. Mayberry, D. J. Brenner, and H. W. Wilkinson. 1989. Legionella quinlivanii $\mathrm{sp}$. nov. isolated from water. Curr. Microbiol. 18:195-197.

4. Birtles, R. J., N. Doshi, N. A. Saunders, and T. G. Harrison. 1991. Second serogroup of Legionella quinlivanii isolated from two unrelated sources in the United Kingdom. J. Appl. Bacteriol. 71:402-406.

5. Bornstein, N., D. Marmet, M. Surgot, M. Nowieki, H. Meugnier, J. Fleurette, E. Ageron, F. Grimont, P. A. D. Grimont, W. L. Thacker, R. F. Benson, and D. J. Brenner. 1989. Legionella gratiana sp. nov. isolated from French spa water. Res. Microbiol. 140:541-552.

6. Brenner, D. J., A. C. McWhorter, J. K. Leete Knutson, and A. G. Steigerwalt. 1982. Escherichia vulneris: a new species of Enterobacteriaceae associated with human wounds. J. Clin. Microbiol. 15:1133-1140.

7. Brenner, D. J., A. G. Steigerwalt, G. W. Gorman, H. W. Wilkinson, W. F Bibb, M. Hackel, R. L. Tyndall, J. Campbell, J. C. Feeley, W. L. Thacker, P. Skaliy, W. T. Martin, B. J. Brake, B. S. Fields, H. V. McEachern, and L. K. Corcoran. 1985. Ten new species of Legionella. Int. J. Syst. Bacteriol. 35:5059.
8. Dennis, J. P., D. J. Brenner, W. L. Thacker, G. Vesey, R. Wait, A. G. Steigerwalt, and R. F. Benson. 1993. Five new Legionella species isolated from water. Int. J. Syst. Bacteriol. 43:329-337.

9. Gorman, G. W., J. M. Barbaree, and J. C. Feeley. 1983. Procedures for the recovery of Legionella from water. Developmental manual. U.S. Department of Health and Human Services, Public Health Service, Atlanta.

10. Karr, D. E., W. F. Bibb, and C. W. Moss. 1982. Isoprenoid quinones of the genus Legionella. J. Clin. Microbiol. 15:1044-1048.

11. Lambert, M. A., and C. W. Moss. 1989. Cellular fatty acid compositions and isoprenoid quinone contents of 23 Legionella species. J. Clin. Microbiol. 27:465-473.

12. Moss, C. W. 1990 . The use of cellular fatty acids for identification of microorganisms, p. 59-69. In A. Fox, S. L. Morgan, L. Larrson, and G. Oldham (ed.), Analytical microbiology methods. Chromatography and mass spectrometry. Plenum Publishing Corp., New York.

13. Moss, C. W., and G. O. Guerrant. 1983. Separation of bacterial ubiquinones by reverse-phase high-pressure liquid chromatography. J. Clin. Microbiol. 18:15-17.

14. Moss, C. W., R. E. Weaver, S. B. Dees, and W. B. Cherry. 1977. Cellular fatty acid composition of isolates from Legionnaires' disease. J. Clin. Microbiol. 6:140-143.

15. Saunders, N. A., N. Doshi, and T. G. Harrison. 1992. A second serogroup of Legionella erythra serologically indistinguishable from Legionella rubrilucens. J. Appl. Bacteriol. 71:402-406.

16. Thacker, W. L., R. F. Benson, L. Hawes, H. Gidding, B. Dwyer, W. R. Mayberry, and D. J. Brenner. 1991. Legionella fairfieldensis sp. nov. isolated from cooling tower waters in Australia. J. Clin. Microbiol. 29:475-478.

17. Thacker, W. L., J. W. Dyke, R. F. Benson, D. H. Havlichek, Jr., B. RobinsonDunn, H. Steifel, W. Schneider, C. W. Moss, W. R. Mayberry, and D. J. Brenner. 1992. Legionella lansingensis sp. nov. isolated from a patient with pneumonia and underlying chronic lymphocytic leukemia. J. Clin. Microbiol. 30:2398-2401.

18. Thacker, W. L., B. B. Plikaytis, and H. W. Wilkinson. 1985. Identification of 22 Legionella species and 33 serogroups with the slide agglutination test. J. Clin. Microbiol. 21:779-782.

19. Verma, U. K., D. J. Brenner, W. L. Thacker, R. F. Benson, G. Vesey, J. B. Kurtz, P. J. L. Dennis, A. G. Steigerwalt, J. S. Robinson, and C. W. Moss. 1992. Legionella shakespearei sp. nov., isolated from cooling tower water. Int. J. Syst. Bacteriol. 42:404-407.

20. Wayne, L. G. D. J. Brenner, R. R. Colwell, P. A. D. Grimont, O. Kandler, M. I. Krichevsky, L. H. Moore, W. E. C. Moore, R. G. E. Murray, E. Stackebrandt, M. P. Starr, and H. G. Trüper. 1987. Report of the Ad Hoc Committee on Reconciliation of Approaches to Bacterial Systematics. Int. J. Syst. Bacteriol. 37:463-464.

21. Wilkinson, H. W. 1988. Hospital-laboratory diagnosis of Legionella infections, 2nd printing, rev. ed. Centers for Disease Control, Atlanta.

22. Wilkinson, H. W., W. L. Thacker, R. F. Benson, S. S. Polt, E. Brookings, W. R. Mayberry, D. J. Brenner, R. G. Gilley, and J. K. Kirklin. 1987. Legionella birminghamensis sp. nov, isolated from a cardiac transplant recipient. J. Clin. Microbiol. 25:2120-2122. 